\title{
DAVID GARNETT RUMINATES ON HOW ONE THING BECOMES ANOTHER YET PURPORTS TO STAY THE SAME.
}

i.

I might be an inheritor in the same manner that every creature inherits something. Yet I inherit the art of translation, which is to say the art of inconsistency in a universe that vows its stability.

Therefore my mother is a translator as is the central role of any mother with implications

for her progeny. I, too, translate from one

to the next so that if I marry one wife, I have married another

or at least the daughter of another mother, inconstant to her husband who took another lover,

translating passions. Marriage, as it were, a translation of the exchange,

the daughter for the woman, the death for the replacement, the art

for the art, the familial for the familiarly irregular. 
ii.

Translate the confusion

of this. Translate the animal

become human until the art

of the translator takes human

back to animal. Translate the pursuit

inside the story, the daughter, the son of

the story and the loop

of the chase

until finally the

translator's arms are mauled

in their own circuit, clasping

their own birthright.

The quarry

translating their denouement, its

besieging, caterwauling

bequest.

inconstant

for constant, perfect rendering

of inheritance slipped through

the hedge and broken away. 